https://doi.org/10.18485/iipe_conv_conf.2021.ch10

\title{
NON-PAPERS OF THE REPUBLIC OF SLOVENIA AND DIFFERENT VIEWS ON THE FUTURE OF THE WESTERN BALKANS REGION
}

\begin{abstract}
Nenad A. Vasić ${ }^{1}$
Abstract: The subject of this scientific paper is the analysis of non-papers of the Republic of Slovenia related to the situation and possible solutions regarding disputes in the Western Balkans region. Given that this proposal in the non-papers refers to high officials in the region and was originally from one of the European Union's member states, the fact is that it has been considered and commented on by states in the Western Balkans region, as well as Kosovo* officials. Yet, apart from stirring an unusually great deal of attention, it has offered some possible solutions. As a result, it is useful to shed some light on non-papers as a form of diplomatic communication, as well as the document in question and its aftermath. Hense, the paper provides a conceptual explanation of the term "non-paper". Further, the paper analyses the content and the form and makes a comparison of seven non-papers identified so far, assessing the effects that these informal documents have had on the Western Balkans, taking into consideration the statements of decisionmakers about the ongoing regional and bilateral disputes. Also, the interests of various actors in the region on this issue were assessed, and this assessment could contribute to a better understanding of what would be an acceptable or unacceptable solution to the disputes. The conclusion is that the possibility of using non-paper as an informal means of communication and an instrument
\end{abstract}

\footnotetext{
${ }^{1}$ Research Fellow, Centre for Neighbouring and Mediterranean Countries. nenad.v@diplomacy.bg.ac.rs.

The paper presents the findings of a study developed as a part of the research project "Serbia and Challenges in International Relations in 2021", financed by the Ministry of Education, Science, and Technological Development of the Republic of Serbia, and conducted by the Institute of International Politics and Economics, Belgrade.
} 
for finding solutions for the Western Balkans region could encourage critical thinking, creativity, and communication among all relevant actors about possible solutions in the future.

Keywords: non-paper of the Republic of Slovenia, Western Balkans, European integration, Euro-Atlantic integration, peaceful settlement of disputes, regional security.

\section{INTRODUCTION}

Various options are being considered concerning the regional future of the Western Balkans countries and Kosovo ${ }^{2}$ in the form of strategists' proposals, politicians' initiatives, or officials-instructed diplomatic activities. The non-paper is one of the forms used in modern diplomatic practice. Indicatively, most of these came out in the first half of the 21st century. The emergence of most non-papers can be traced back to the months of April or May. Non-papers are neither a novelty nor a legal exception in the science of international relations and the history of diplomacy; however, they are among the less common activities of the experts who write, comment on, or interpret them, and may be completely ignored.

Nevertheless, as far as the Republic of Serbia and other Western Balkan countries are concerned, the latter did not happen. In Serbia, they have all been duly commented on, whether by government officials, journalists, or by various experts.

\footnotetext{
2 The Agreement on international representation and cooperation of Kosovo was reached on February 24, 2012, between the government representatives of the time: Borislav Stefanovic for Belgrade and Edita Tahiri for Priština, in Brussels, with the mediation of the current High Representative for the EU, Baroness Catherine Ashton.

In that sense, Kosovo* is the only title that should be used in international cooperation.

The footnote to be implied with the asterisk in the former point 2. shall quote: "This designation is without prejudice to positions on status, and is in line with UNSC 1244 and the ICJ Opinion on the Kosovo Declaration of Independence." Договор о регионалном представљању и сарадњи, https://www.srbija.gov.rs/kosovo-metohija/ 168200, visited 30 March 2021.
} 


\section{NOTION AND ELEMENTS OF THE NON-PAPER IN INTERNATIONAL CORRESPONDENCE}

Non-paper ${ }^{3}$, as far as international law is concerned, is an unofficial document, according to experts. In the words of the ex-ambassador, David Dašić, non-paper is the least formal ${ }^{4}$ type of diplomatic communication between the officials of two or more countries. "It treats, analytically and circumspectly, some particularly sensitive bilateral issues, seeking to initiate diplomatic dialogue based on them. ${ }^{5}$ According to professor Dašić, the non-paper is thus a non-binding or at least "a document loosely binding" "for its author. It is mandatory for diplomatic non-papers to be put on memorandum. For that matter, the non-papers are handed out before or after diplomatic meetings with the purpose of further consideration and seeking possible solutions to disputed issues. The other party cannot refer to such a document, nor is it required to answer officially. In his widely renowned book, "Satow's Diplomatic Practice", Sir Ivor Roberts of Trinity College, Northern Ireland, UK, treats a non-paper as a demarche (Fr. démarche), a diplomatic step or move. "Non-paper is less formal than a "bout de paper". This is a way for a government to present its politics "off-the-record", avoiding public authorization of the positions stated. This allows for further discussion on certain proposals while waiting for feedback. This approach is functional in multilateral diplomacy. A third party can take it on itself to draft a concept of a non-paper to examine the degree of compatibility of the participants' views, devoid of any obligation or responsibility for the views stated therein.?

\footnotetext{
${ }^{3}$ In this scientific work, the term "non-paper" is defined as an unofficial and non-administrative electronic text of a document by a government, without stating of its author, showing the position, attitude, and the requirements of other governments in resolving issues in international relations.

${ }^{4}$ Давид Ђ. Дашић, Савремена дипломатија, Мултидисциплинарни центар за подстицање интеграционих процеса и хармонизацију права/Привредни саветник д.о.о. Београд, 2008, стр. 149. Види и: Давид Ђ. Дашић, Историја дипломатије: еволуција дипломатског метода у политичкој историји, Институт за међународну политику и привреду, Београд, 2015, стр. 17-699. Такође о дипломатији у теорији и пракси види: Џоф Р. Бериџ, Дипломатија: теорија и пракса, ИП „Филип Вишњић”/Академија за дипломатију и безбедност, Београд, 2008, pp. 11-306.

${ }^{5}$ Дашић, Савремена дипломатија, ibidem, p. 149.

${ }^{6}$ Дашић, Савремена дипломатија, ibidem, p. 149.

7 Satou: Diplomatska praksa, Urednik izdanja Ser Ajvor Roberts, HOLLIWELL-NEOPREN, Beograd, 2009, p. 53.
} 
It should be mentioned here that there are various sorts of non-papers. Our scientific interest is in political non-papers. These are designed by government officials in cooperation with experts in the fields and matters of national interest. Such a document is entirely non-binding, and it does not reveal its authors, despite the fact that the address from which it is issued is unofficially known.

It is important to note that a non-paper is not the same as an aidemémoire ${ }^{8}$, which is used in state official meetings and diplomatic missions. An aide-mémoire is a resume of an address, prepared before the dialogue takes place and handed down to the other party after the meeting. This is done to eliminate any doubts or ambiguity concerning the participants' standpoints. This is the purpose of the aide-mémoire. It authenticates a government's positions, which the Foreign Minister states to the diplomatic mission of the state accredited ${ }^{9}$. According to Dašić, the aide-mémoire is a short, concise, and informal document, which actually has elements of commitment. It only comprises the date, address and the hallmark "of a diplomatic mission". ${ }^{10}$

Another form of communication used by officials in modern diplomacy is non-papers. So, the officials of the State Department ${ }^{11}$ used non-papers in correspondence during the Israeli-Arab political conflict in 1980. One of the current non-papers is the non-paper on the implementation of the Agreement ${ }^{12}$ in the field of foreign and security policy between the EU and the UK, in the field of foreign and security policy.

\footnotetext{
${ }^{8}$ In this scientific work, the notion of "aide-mémoire" is defined as an official government document, which gives a résumé of the most significant points, or a suggestion for consensus in international relations and diplomatic correspondence.

${ }^{9}$ Дашић, Савремена дипломатија, ibidem, p. 149.

${ }^{10}$ Дашић, Савремена дипломатuja, ibidem, p. 149.

${ }^{11}$ See: Телеграм State Department-a послат из Вашингтона, амбасади Сједињених Америчких Држава у Тел Авиву 19. септебра 1979. године: Telegram From the Department of State to the Embassy in Israel, in: Editor Alexander R. Wieland, United States Government Publishing Office, Washington DC, 2018, pp. 952-955.

12 Non-paper on the implementation of the EU-UK TCA in the field of foreign and security policy, Council of the European Union/General Secretariat, WK 8452/2021 INIT LIMITE Brussels, 24 June 2021, pp. 1-2.
} 
Unlike the aide-mémoire, which is a diplomatic document, the nonpaper, more political in nature, can be freely discussed or officially commented upon. Therefore, the political non-papers do not represent official documents on a memorandum with a reference number and a reference in the Book of Protocol. Its authors are mostly anonymous, apart from the sender. Essentially, until they are accepted by the state institution or international organization's officials, or forums, they remain merely informal files, and therefore, non-papers.

\section{CURRENT NON-PAPER FOR THE WESTERN BALKANS BY THE REPUBLIC OF SLOVENIA}

The modern history of international relations and diplomacy records as many as eight non-papers regarding the Western Balkans region. The public exposure and comments made by officials from the Western Balkans countries and Kosovo*, both at home and abroad, are shared by all.

The first unofficial document, a non-paper, to come out was on the subject of Bosnia and Herzegovina ${ }^{13}$, designed by experts monitored by the Minister of Foreign and European Affairs of the government of the Republic of Croatia, Gordan Grlić Radman. The Croatian expert team was to be joined by their counterparts from another five countries: the Republic of Slovenia, the Republic of Hungary, the Republic of Bulgaria, the Republic of Greece, and the Republic of Cyprus. The document expressed positions close to those of the leader of the Croatian Democratic Union of Bosnia and Herzegovina, Dragan Čović. Incidentally, Minister Grlić Radman has presented the Paper on a session of the Foreign Affairs Council of the European Union, Mart 22, 2021 in Brussels.

The second paper, the most controversial and most commented on, and the one actually in focus, is related to the Republic of Slovenia and its Prime Minister, Janez Jansa. After the failure of a prospective political agreement with only two separate Agreements on Economic Normalization ${ }^{14}$ of relations

${ }^{13}$ Ministar Grlić Radman predstavio non-paper o Bosni I Hercegovinina Vijeću za vanjske poslove EU, http://www.mvep.hr/hr/mediji/priopcenja/,36443.html, visited 9 September 2021.

${ }^{14}$ See: Economic Normalization, y: Анализа докумената потписаних у Белој кући, Центар за друштвени дијалог и регионалне иницијативе, Београд, 2020, pp. 17-18 and 22-23. 
between the Republic of Serbia (represented by President Alexandar Vučić) and the Kosovo Albanians (represented by the Prime Minister of Kosovo* at the time, Avdulah Hoti) mediated by the then US President Donald John Trump (4 September 2020), eagerness rose to make this plausible. The initiative was made by the President of the Republic of Slovenia, Borut Pahor, in an address in the Parliament of the Republic of North Macedonia on September 25, 2020, "I should, thereby, like to express my assessment which, be it exact, can prove significant: in the case that the enlargement of the EU does not occur, or it gets delayed, the thesis is that the disintegration of the ex-Yugoslavia has not been completed, and that it is necessary to introduce ethnical borders in place of the existing ones".

Experience has taught us that such a process is unlikely to take place peacefully, avoiding the impending conflicts that could destabilise and shake Southeast Europe's security. Therefore, we have stated repeatedly that an enlargement of the EU into the Western Balkans is an exclusively political question, requiring from the $\mathrm{EU}$ an even more circumspect strategy ${ }^{15}$. Even as early as March 10, 2021, at the extraordinary assembly on the topic of the High Representative in the Republic of Srpska Parliament in Banja Luka, Milorad Dodik mentioned a visit of a certain European official to Sarajevo, enquiring at a Presidency assembly about the prospect of a peaceful disintegration of Bosnia and Herzegovina. "I come before a prominent group, mind you, a prominent group in the EU, who have envoyed me to ask you: Are you capable of splitting peacefully here in Bosnia and Herzegovina?"16

It was the Slovenian President Pahor who posed this question on March 5, 2021, during the informal part of the visit to the Presidency members in Sarajevo, Milorad Dodik, Šefik Džaferović, and Zvonko Komšič. Only Milorad Dodik replied affirmatively. The other two remained silent. And for two reasons: it is not customary in statesman communication to comment on any

${ }^{15}$ Govorpredsednika Pahorjanaslavnostniseji Sobranja Republike Severne Makedonije, https://www.predsednik.si/up-rs/uprs.nsf/objave/04908438A80F7354C12585EE0044 9283?OpenDocument, visited 19 April 2021.

${ }^{16}$ Posebna sjednica NSRS o visokom predstavniku; Obraćanje Milorada Dodika, https://www.youtube.com/watch?v=C7mgcMDMrMI\&t=4087s, 1:07:47-1:08:00, visited 13 August 2021. 
specific topic unless it has been pre-arranged in a common announcement. There was no disruption to Pahor's visit by his hosts.

Even before Pahor's visit to Bosnia and Herzegovina, the non-paper was written in Ljubljana, the Republic of Slovenia, under the supervision of Slovenian president Janez Jansa. One of the Slovenian web-portals, necenzurisano. $\mathrm{si}^{17}$, has made public the entire contents of the non-paper dated March 15, 2021, titled: Western Balkans- a way forward..$^{18}$ According to the makers of the Slovenian non-paper, after the Council of Thessaloniki conclusions on June 20,2003, although the enlargement of the EU has been provided, "there remain unresolved the national issues of the Serbs, Albanians, and Croats". ${ }^{19}$ We notice the oddity of filing the Republic of Croatia under the Western Balkans region, which is significant in terms of the BosniaHerzegovina Croats. Yet another attempt has been made to solve the nationality issues by shifting the state borders and unifying the three dominant nations within themselves. The spur for such a move was the stability of the governments of the Republic of Serbia, the Republic of Croatia and the Republic of Albania. The part of the Slovenian non-paper concerning the vision offered for solving the unresolved national issues is by all means the most interesting.

\subsection{The Albanian national issue and its solution}

According to the Slovenian non-paper, the Albanian national issue is to be solved basically by unifying into a single state.

"a) The unification of Kosovo and Albania. In Kosovo, 95\% of the population wishes to unify with the Albanians, from whom they trace their origins. The situation is similar in Albania. The border between Albania and

\footnotetext{
${ }^{17}$ See: Primož Cirman, Vesna Vuković, Objavljamo dokument o razdelitvi BiH, ki ga išče ves Balkan, https://necenzurirano.si/clanek/aktualno/objavljamo-slovenski-dokument-orazdelitvi-bih-ki-ga-isce-ves-balkan-865692, visited 15 April 2021.

${ }^{18}$ Western Balkans - a way forward, https://necenzurirano.si/clanek/aktualno/objavljamoslovenski-dokument-o-razdelitvi-bih-ki-ga-isce-ves-balkan-865692\#gallery-2, visited 15 April 2021.

${ }^{19}$ Western Balkans - a way forward, ibidem.
} 
Kosovo does not exist, and the Serbian parts of Kosovo would be guaranteed a special status, after the model of South Tyrol." ${ }^{\prime 2}$

\subsection{The Serbian national issue and its solution}

The Serbian national issue would also be solved by unification.

"b) By the joining of most of the territory of the Republic of Srpska to Serbia.

The Serbian national issue can mostly be solved by joining the largest part of the Republic of Srpska to Serbia. In that case, Serbia would agree to the unification of Kosovo with Albania."21

\subsection{The Croatian national issue and its solution}

“c) The Croatian national issue can be solved:

- by joining the majority Croat cantons of Bosnia and Herzegovina to Croatia.

- by granting a special status to the Croatian parts of Bosnia and Herzegovina, after the model of Southern Tyrol."22

The Slovenian non-paper considers whether or not Bosnians in Bosnia and Herzegovina will benefit from the country's potential integration into the European Union.

"d) In this way, the Bosnians would gain an independent, functional state and take full responsibility for it. The citizens would state their will in a referendum, whether they are inclined to an EU future or to one outside of the EU (Turkey). For the time being, an overwhelming majority of the Bosnians support the European perspective, but should the chaos of the increasing influence of Turkey and radical Islam prevail, the situation may deteriorate drastically in the next decade."23

${ }^{20}$ Western Balkans - a way forward, ibidem.

${ }^{21}$ Western Balkans - a way forward, ibidem.

22 Western Balkans - a way forward, ibidem.

${ }^{23}$ Western Balkans - a way forward, ibidem. 
An essential element of the Slovenian non-paper deals with the European Union's "Three Must Initiative" in the function of economic stabilization, development, better infrastructure, energy, and ecology. The experts of the European Commission would prepare the plan.

"e) In cooperation with other factors in the region, like the "Three Must initiative", the EU starts the implication of an all-encompassing economic programme for stabilization, better infrastructural and energetic connection of the Region, and ecological rehabilitation (the EC has already prepared some segments of this plan)." ${ }^{24}$

Finally, in accordance with the European Commission's plan, the decisions would be endorsed and confirmed by the assemblies of the Western Balkans states and Kosovo*, all with the goal of accelerating euro integration.

"f) After the procurement and ratification of all the necessary bilateral decisions in the region, the admission negotiations for the EU and NATO membership would be accelerated." 25

With this aim, the Slovenian non-paper envisages six actions:

“a) An implicit assessment of the conditions for implementation of the plan with the decision-makers in the region (in progress);

"b) An implicit assessment of the supportiveness toward the plan of the decision-makers in the international community (in progress);

“c) An encompassing program of presenting the plan to the public, (regarding the varying atmosphere in different parts of the region);

"d) If the EU, the US, and the majority of decision-makers in the region agree with the plan and the steps to its implementation, the EU will formally start the initiative;

"e) The process of communicating with various aim groups will be started;

${ }^{24}$ Western Balkans - a way forward, https://necenzurirano.si/clanek/aktualno/objavljamoslovenski-dokument-o-razdelitvi-bih-ki-ga-isce-ves-balkan-865692\#gallery-2-https:// necenzurirano.si/clanek/aktualno/objavljamo-slovenski-dokument-o-razdelitvi-bih-ki-gaisce-ves-balkan-865692\#gallery-3, visited 15 April 2021.

${ }^{25}$ Western Balkans - a way forward, https://necenzurirano.si/clanek/aktualno/objavljamoslovenski-dokument-o-razdelitvi-bih-ki-ga-isce-ves-balkan-865692\#gallery-3, visited 15 April 2021. 
“f) All the required bilateral procedures for the plan's implementation will be set off, synchronized, and completed legally, in a logical sequence."26

In the original text of the Slovenian non-paper, there is also the thesis under f) with a footnote. It is important to give a commentary here on the original text of the formerly mentioned non-paper.

Finally, if the implicit assessment and correction of the plan reveal the need for consent from regional and international decision-makers, which cannot be guaranteed, the non-paper will remain just that: a non-paper.

\section{DIFFERENT REACTIONS OF RELEVANT ACTORS TO SLOVENIAN NON-PAPER AND ISSUE-SOLVING PROSPECTS IN THE WESTERN BALKANS}

It can be stated that there are a number of non-paper options for solving issues, bilateral problems, and open questions in the Western Balkans. The Slovenian non-paper is of particular interest. Its release sparked a flurry of reactions not only in the Republic of Serbia, but also in the West Balkans and Kosovo*, as well as around the world. Here, we shall refer to the most significant ones.

The journalist Sead Naumović first brought to the public's attention the existence of the Slovenian non-paper. This was on his web portal, politicki.ba, on April 12, 2021. Slovenian Prime Minister Janša handed over the draft of the non-paper to the president of the European Council, Charles Michel, and to the current Canceller of the Federal Republic of Germany, Angela Merkel. According to Janša, it starts from the plan Vučić-Taci on the redrawing of the borders of Serbia and Kosovo. Yet, here it is taken several steps further, with the prospective secession of the entity of the Republic of Srpska, the annexation of parts of Montenegro and North Macedonia with the Albanian majority to Albania, and, finally, the annexation of Western Herzegovina to Croatia.

A sub-variant of Janša's plan includes the formation of three national republics in Bosnia and Herzegovina. The Serbian and Croatian republics would

\footnotetext{
${ }^{26}$ Western Balkans - a way forward, https://necenzurirano.si/clanek/aktualno/objavljamoslovenski-dokument-o-razdelitvi-bih-ki-ga-isce-ves-balkan-865692\#gallery-3, visited 15 April 2021.
} 
be closely bound to their respective motherlands, whereas the Bosnian republic would be granted a corridor through to the international sea waters, guaranteed by NATO. ${ }^{27}$ Thus, whether according to the Slovenian non-paper or by the aforementioned sub variant, the proceedings should be peaceful and under the patronage of the European Union and the North Atlantic Alliance.

On the morning of February 12, 2021, the viral Priština web-portal in Albanian, Telegrafi, published an interview with the Slovenian president, Borut Pahor, just before his visit to Kosovo*, in which he claims to have no knowledge of anything to do with a non-paper. "Let me repeat what I have said many times: I find the idea of border redrawing utterly unacceptable. Let me get this clear: I do not support the idea of border redrafting in the region because it has never yet ended well."28

That same day, a tweet came out by the president of the European Parliament's Committee for Stabilization and Association for the Republic of Serbia, Tanja Fajon, and a re-tweet ensued by the journalist of the daily "Delo", Peter Zerjavić. First, Mrs. Fajon tweeted, "With his initiative for a peaceful dissolution of Bosnia and Herzegovina, Janša is trying to finalise the old Milošević- Tudjman plan for the formation of a Greater Serbia and Greater Croatia." ${ }^{29}$ Further on, she expresses her doubt that this can be done peacefully. "Such irresponsible behaviour could lead to another war in the Balkans!" ${ }^{30}$ Soon came a re-tweet by the journalist Zerjavić: "Such details rarely go public. According to the Croatian member of the Presidency of Bosnia and Herzegovina, Željko Komšić, President Borut Pahor has mentioned certain circles in the EU eager for the completion of the breaking of Yugoslavia, enquiring about a peaceful dissolution of Bosnia and

${ }^{27}$ Sead Numanović, Janša predvodi države EU koje žele "veliku Srbiju” i komadanje BiH, Crne Gore, Sjeverne Makedonije, https://politicki.ba/news/read/15926, visited 25 August 2021.

${ }^{28}$ Muhamet Hajrullahu, Ekskluzive, flet për Telegrafin Presidenti slloven Pahor një ditë para vizitës në Kosovë: Nuk e kam të njohur non-paper-in, idetë mbi ndryshimin e kufijve janë plotësisht të papranueshme, https://telegrafi.com/ekskluzive-flet-per-telegrafin-presidentislloven-pahor-nje-dite-para-vizites-ne-kosove-nuk-e-kam-te-njohur-non-paper-idete-mbindryshimin-e-kufijve-jane-plotesisht-te-papranueshme/, visited 27 August 2021.

${ }^{29}$ Tanja Fajon, https://twitter.com/tfajon/status/1381612387896336385, visited 25 August 2021.

30 Tanja Fajon, ibidem. 
Herzegovina." ${ }^{31}$ On that occasion, Zerjavić also attached a link to the website of the daily journal "Oslobodjenje". On the same day, a member of the Bosnia and Herzegovina Presidency, Željko Komšić, commented on President Pahor's visit to the Sarajevo-based "Oslobodjenje". Allegedly, Pahor had asked: "Can you peoples of Bosnia and Herzegovina split up peacefully?" Komšić claimed that he and Šefik Džaferović said a peaceful separation was not possible, while the Chairman, Milorad Dodik was of an opposite opinion." ${ }^{32}$

To the entire tweet by the journalist Zerjavić reacted Mrs. Fajon with yet another re-tweet: "If the $\mathrm{BH}$ media reports, and the regional diplomatic statements are true, the isolation of Slovenia could prove very detrimental. Thank you for clearing it out." 33 To this all, reacted the Slovenian Prime Minister, Janša, "a solution for the development of the region and the EU perspective of the countries of the Western Balkans is being worked on; Yet with writings of this kind, this aim is being sabotaged". ${ }^{34}$

The next day, Prime Minister Janez Janša negated the authenticity of the geographic map, posted by the Macedonian web-portal news $1 . \mathrm{mk}^{35}$, on the redrawing of borders in the Western Balkans. He tweeted, among other matters, "False map..." 36

31 Peter Žerjavič, https://twitter.com/tfajon/status/1381612387896336385, visited 25 August 2021.

${ }^{32}$ Komšić potvrdio da je Pahor pitao da li je moguć miran razlaz u BiH, pa otkrio šta je Dodik odgovorio na to,https://www.oslobodjenje.ba/vijesti/bih/komsic-potvrdio-da-je-pahorpitao-da-li-je-moguc-miran-razlaz-u-bih-pa-otkrio-sta-je-dodik-odgovorio-na-to-647019, visited 25 August 2021

${ }^{33}$ Tanja Fajon, https://twitter.com/tfajon/status/1381613982340034564, visited 25 August 2021.

${ }^{34}$ Janez Janša, https://twitter.com/JJansaSDS/status/1381546181956878340, visited 26 August 2021.

35 Јанша предложил поделба на границите на Балканот?, https://news1.mk/archives/ 25643, visited 26 August 2021.

${ }^{36}$ Janez Janša, https://twitter.com/JJansaSDS/status/1381953503506087942, visited 26 August 2021. 


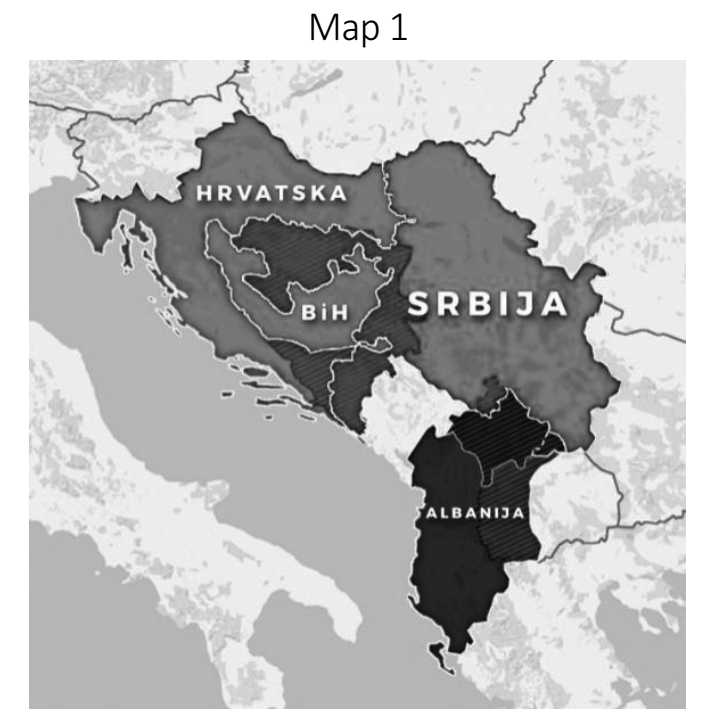

Source : https://news1.mk/archives/25643

For spreading the news of this "false map", Janša accused Mr. Drago Kos, and Mrs. Tanja Fajon. So began the polemics between Prime Minister Janša and Mrs. Fajon on the Tweeter. Regarding the false map, Fajon re-tweeted, among other quotes, "You are lying..." 37

For the first time, a public statement concerning the Slovenian non-paper came from the Serbian President, Alekandar Vučić, and the member of the Bosnia and Herzegovina Presidency from the Republic of Srpska, Milorad Dodik, on April 15, 2021. On the occasion of receiving 10,000 doses of vaccine in the "Torlak" Virusology Institute in Belgrade (the vaccines donated by the officials of the Republic of Serbia to the Republic of Srpska), Dodik commented on the Slovenian non-paper. So has the Serbian President, Vučić. President Vučić was the first to speak: "I have not seen any initiative, and so I am not ready to condemn, or to praise anything I have not seen" ${ }^{\prime 38}$ On that occasion,

${ }^{37}$ Tanja Fajon, https://twitter.com/tfajon/status/1381964257072271370, visited 26. August 2021.

${ }^{38}$ Aleksandar Vučić o non-paperu: Ako ja ne znam šta je to, ne možete znati ni vi, https://radiosarajevo.ba/vijesti/regija/aleksandar-vucic-o-non-paperu-ako-ja-ne-znam-staje-to-ne-mozete-znati-ni-vi/413845, visited 26 August 2021. 
President Vučić repeated his view against redrawing Serbia's state borders. This was followed by a statement from the then Chairman of the Presidency of Bosnia and Herzegovina, Dodik: "I believe that peaceful separation should be held as relevant in the future. My conception is of a peaceful separation, and not a war. Serbia, on the other hand, has its international bonds, as a guarantee of the Dayton Treaty, and we understand that". ${ }^{39}$ On that same day, reactions ensued from the president of the Democratic Action Party, Bakir Izetbegović. Commenting on the Slovenian non-paper, he said that it holds dangerous ${ }^{40}$ theses, not only for Bosnia and Herzegovina, but also for the Western Balkans region and even for the EU. That same day, as a reply to the question of Voice of America journalist, Jasmina Djurdjić, came the answer of the speaker of the State Department: "The US highly regards its long-lasting partnership with Bosnia and Herzegovina, and remains devoted to the common aim of a democratic, inclusive, and prosperous $\mathrm{BiH}$, moving towards full Euro-Atlantic integration." ${ }^{11}$ The following was also stated: "The United States is strongly supportive of all the aspirant countries from the Western Balkans on their way to the EU." 42 (It is important to stress here that US officials are active in matters of the enlargement of the EU, promoting not only a lasting peace, but also the prosperity of the West Balkans region). The next day, another two reactions came, namely, from the Russian Federation and the Republic of Albania.

On April 16, 2021, Serbian foreign minister Nikola Selaković paid an official visit to the Russian Federation and its foreign minister, Sergey Viktorovich Lavrov. After the meeting, Lavrov declared the official position of the Russian Federation regarding the Slovenian non-paper. "Those are unacceptable, provocative, and highly damaging statements". ${ }^{43}$ Minister Lavrov has

${ }^{39}$ Aleksandar Vučić o non-paperu: Ako ja ne znam šta je to, ne možete znati ni vi, ibidem.

40 Izetbegović: "Non paper" iznosi teze opasne po Evropu, a ne samo BiH! https://politicki.ba/ news/read/15980, visited 26 August 2021.

${ }^{41}$ Milena Đurđić, State Department: Podržavamo suverenitet $i$ teritorijalni integritet BiH, https://ba.voanews.com/a/sad-state-department-bih-suverenitet/5854115.html, visited 15 April 2021.

42 Đurđić, State Department: Podržavamo suverenitet i teritorijalni integritet BiH, ibidem.

${ }^{43}$ Выступление и ответы на вопросы СМИ Министра иностранных дел Российской Федерации С. В. Лаврова в ходе совместной пресс-конференции с Министром 
essentially reiterated the Russian Federation's and its president, Vladimir Putin's, familiar official positions. "There exists Resolution 1244 of the UN Security Council that has not been cancelled. Responsible politicians (more so, European government leaders) have no right to put up ideas that brutally erode the very concept defined by Resolution 1244 of the EU Security Council. It is further stated that the Security Council respects the sovereignty of Serbia, and a proposition is given for a specific treatment to be demanded for Kosovo in the Priština-Belgrade negotiations". ${ }^{4}$

The existence of a non-paper and of a redesigned Western Balkans map was confirmed by the Albanian Prime Minister, Edi Rama, while participating in the "ZGJEDHJE 2021 në $V+$ " show, having had an insight into the documents. "I have also seen this document that has emerged. I have no comment on that". 45

On the same day, the Slovenian Prime Minister, Janša, denied the existence of a Slovenian non-paper ${ }^{46}$, thus condemning it, in a phone conversation with Bosnian member of the BH Presidency, Šefik Džeferović.

According to the Croatian Prime Minister, Andrej Plenković, none ${ }^{47}$ of the officials have received the Slovenian non-paper.

Starting on April 19, 2021, the president of the Independent Socialdemocrats Union, Milorad Dodik, started a campaign for a peaceful separation

иностранных дел Республики Сербии Н.Селаковичем, Москва, 16 апреля 2021 года, https://www.mid.ru/ru/vizity-ministra/-/asset_publisher/ICoYBGcCUgTR/content/ id/4689215, visited 19 April 2021.

${ }^{44}$ Выступление и ответы на вопросы СМИ Министра иностранных дел Российской Федерации С.В.Лаврова в ходе совместной пресс-конференции с Министром иностранных дел Республики Сербии Н.Селаковичем, Москва, visited 19 April 2021, ibidem.

${ }^{45}$ ZGJEDHJE2021 në V+, https://www.facebook.com/edirama.al/videos/923087461838528, 2:15:45-2:15:50, visited 26 August 2021

${ }^{46}$ Rijad Durkić, Janša nazvao Džaferovića: Ne postoji „non paper” o prekrajanju granica, podržavam integritet BiH, https://www.klix.ba/vijesti/bih/jansa-nazvao-dzaferovica-nepostoji-non-paper-o-prekrajanju-granica-podrzavam-integritet-bih/210416131, visited 27 August 2021.

${ }^{47}$ Navodni Janšin non-paper o BiH sam vidio na portalu, Hrvatska ga nije dobila', https://www.jutarnji.hr/vijesti/ hrvatska/navodni-jansin-non-paper-o-bih-sam-vidio-naportalu-hrvatska-ga-nije-dobila-15065912, visited 27 August 2021. 
in Bosnia and Herzegovina. He has leased time on the u-Tube channel for the broadcast of two of his videos to that end: 1 . Dodik on a peaceful separation in $\mathrm{BiH}^{48}$; 2. A peaceful separation of $\mathrm{BiH}$ is the best thing for all. ${ }^{49}$

Not long after this, an official view of the EU was heard from the European Commission speaker, Eric Mamer: "The position of the EU on this is well known. We are categorically against any border changing".50

In the name of the United Kingdom, regarding the Slovenian non-paper and the views stated by the ex-diplomat and current leader of the "Study of Disintegration" project of Cambridge University's Centre for Politics, Timothy Less, the British Ambassador to Sarajevo, BiH, Mathew Field reacted. Namely, Ambassador Field gave an interview to the journalist of the Sarajevo Daily Avaz, Erdin Halimić, on May 7, 2021. On that occasion, he said, "...of the documents that are so bad, nobody would claim them". ${ }^{51}$ He also commented on Timothy Less' propositions: "Timothy Less does not speak for the United Kingdom". ${ }^{52}$

In the Republic of Slovenia, journalist Novica Mihajlovićs3 of the daily "Delo" magazine wrote about the Slovenian non-paper, confirming its existence and adding that it was too risky to be made public. The paper's existence was also confirmed by Milan Kučan. "Also, this is denied by our Prime Minister, while such a non-paper obviously exists. It turns out that in

${ }^{48}$ Додик о мирном разлазу БиX, https://www.youtube.com/watch?v=Shyao7TZ-DQ visited 26 August 2021.

${ }^{49}$ Мирни разлаз БиХ је најбољи за све, https://www.youtube.com/watch?v=QTOW jMh9bkw, visited 26 August 2021.

50 Portparol EK: Pitanje granica na Zapadnom Balkanu, zauvek zatvoreno', https://www. slobodnaevropa.org/a/31223440.html, visited 26 August 2021.

${ }^{51}$ Erdin Halimić, Ambasador Velike Britanije u BiH Metju Fild za „Avaz”: Timoti Les ne govori uime Ujedinjenog Kraljevstva, https://avaz.ba/vijesti/bih/649925/ambasador-velikebritanije-u-bih-metju-fild-za-avaz-timoti-les-ne-govori-uime-ujedinjenog-kraljevstva?fbclid =IwAR2uixGroqM5d4-P1-PCKhWi_ef7Sv2fI_xOOvlw3pGLYUNOycoZPt9v3a8, visited 13 May 2021.

52 Halimić, Ambasador Velike Britanije u BiH Metju Fild za "Avaz": Timoti Les ne govori u ime Ujedinjenog Kraljevstva, ibidem.

${ }^{53}$ Novica Mihalović, Slovenski non-paper obstaja, a je za javnost preveč tvegan, https://www.delo.si/novice/ slovenija/slovenski-non-paper-je-za-javnost-prevec-tvegan/, visited 27 August 2021. 
Brussels they know who the author is, as well as about its contents, but they are loath to reveal it because of its harmfulness to international relations".54

Another reaction to the Slovenian non-paper came from the president of the Socialist International, Jorgos Papandreou. In an author's text for the Greek daily, Ekatimerini, he confirmed the existence and circulation of the Slovenian non-paper ${ }^{55}$ but also of another, Franco-German non-paper (we will not deal with this non-paper in this study).The Slovenian non-paper is also opposed by the President of the Republic of Montenegro and the Prime Minister of Kosovo*.

\section{THE FINAL CONCLUSION}

Non-papers, particularly the Slovenian non-paper, dominated the first half of this year in the West Balkans region. Using the historical and comparative method, as well as a content analysis of the publicly available Slovenian nonpaper, we can draw four conclusions: 1 . From its emergence until now, the Slovenian non-paper has become no one's official document; 2 . A common trait is the Slovenian view of a peaceful, consensual solving of issues and the open questions in the bilateral and multilateral relations of states, including Kosovo*; 3. Depending on the interests of the relevant actors, integration is being facilitated into the European Union, the North Atlantic Alliance, and other organizations, institutions, and forums, according to the free inclination of state officials; 4. The position of the United Nations and the Security Council

\footnotetext{
54 Драган Штављанин, Први председник Словеније: крај Југославије је био неминован, https://www.slobodnaevropa.org/a/prvi-predsednik-slovenije-milan-kucan-intervju/ 31313878.html, visited 28 June 2021.

It is important to mention that (at the then Prime Minister's bidding), Milan Kučan, in the role of the Prime Minister's informer, made a suggestion for a constitutional form of Bosnia and Herzegovina without a change in the state's territories. See on this topic: POROČILO G. MILANA KUČANA, POROČEVALCA PREDSEDNIKU VLADE REPUBLIKE SLO.NIJE G. BORUTU PAHORU O MOŽNIH POTEH ZA USPEŠNO NADALJEVANJE PROCESA SPREMEMB USTAVNEGA REDA V REPUBLIKI BOSNI I HERCEGOVINI, REPUBLIKA SLOVENIJA/KABINET PREDSEDNIKA VLADE, Ljubljana, 11. 6. 2021, pp. 3-17.

${ }^{55}$ George A. Papandreou, Europe and the Balkans - opening Pandora's box?, https://www.ekathimerini.com/opinion/1164270/europe-and-the-balkans-openingpandora-s-box/, visited 19 July 2021.
} 
is being confirmed, with the implementation of Resolution 1244, endorsed on June 10, 1999. The Slovenian non-paper was notable for igniting heated debate and public debate among the relevant actors, particularly in the Western Balkans states and Kosovo*, which felt compelled to comment on it.

The fact that no decisions were made on that occasion in the Western Balkans and Kosovo* states, as well as in international organizations, institutions, and forums, is significant. The only one who publicly saluted the Slovenian non-paper in the part concerning Bosnia and Herzegovina, that is, the dissolution of the Republic of Srpska and its annexation to the Republic of Serbia, was Milorad Dodik.

Nonetheless, the non-paper, whether Slovenian, which was the focus of our scientific analyses, or others yet to be written and sent, should be considered, treated, and interpreted in public as well as in negotiations between state officials and Kosovo* in the Western Balkans region. Principally, they should be endorsed (to a greater or lesser extent) or altogether discarded, eventually, should they prove to be unacceptable or inapplicable, especially if they do not contribute to world and regional peace, socioeconomic progress, political stability, and the rule of law.

\section{BIBLIOGRAPHY}

Aleksandar Vučić o non-paperu: Ako ja ne znam šta je to, ne možete znati ni vi, https://radiosarajevo.ba/vijesti/regija/aleksandar-vucic-o-non-paperuako-ja-ne-znam-sta-je-to-ne-mozete-znati-ni-vi/413845, posećeno 26. avgust 2021.

Бериџ Џоф Р., Дипломатија: теорија и пракса, Издравачко Предузеће „Филип Вишњић”/Академија за дипломатију и безбедност, Београд, 2008. (Berrige, Joeff P, Diplomacy: Theory and Practice)

Cirman Primož, Vuković Vesna, Objavljamo dokument o razdelitvi BiH, ki ga išče ves Balkan, https://necenzurirano.si/clanek/aktualno/objavljamoslovenski-dokument-o-razdelitvi-bih-ki-ga-isce-ves-balkan-865692, obiskal 15. april 2021. (Cirman Primož, Vukovic Vesna, "We are announcing the Document on separation of $\mathrm{BH}$, desired by the whole of Balkans")

Дашић Давид Ђ., Савремена дипломатија, Мултидисциплинарни центар за подстицање интеграционих процеса и хармонизацију 
права/Привредни саветник д.о.о. Београд, 2008. (Dašić David Dj, Modern Diplomacy)

Дашић Давид Ђ., Историја дипломатије: еволуција дипломатског метода у политичкој историји, Институт за међународну политику и привреду, Београд, 2015. (Dašić David Dj, History of diplomacy: evolution of the diplomatic method in political history)

Додик о мирном разлазу БиX, https://www.youtube.com/watch?v=Shyao7 TZ-DQ, посећено 26. август 2021. (Dodik on a peaceful separation of BH) Договор о регионалном представљању и сарадњи, https://www.srbija. gov.rs/kosovo-metohija/ 168200, посећено 30. март 2021. (The Agreement on regional representation and cooperation)

Durkić Rijad, Janša nazvao Džaferovića: Ne postoji „,non paper” o prekrajanju granica, podržavam integritet BiH, https://www.klix.ba/vijesti/bih/jansanazvao-dzaferovica-ne-postoji-non-paper-o-prekrajanju-granicapodrzavam-integritet-bih/210416131, posećeno 27. avgust 2021.

Đurđić Milena, State Department: Podržavamo suverenitet $i$ teritorijalni integritet BiH, https://ba.voanews.com/a/sad-state-department-bihsuverenitet/5854115.html, posećeno 15. april 2021.

Economic Normalization, у: Анализа докумената потписаних у Белој кући, Центар за друштвени дијалог и регионалне иницијативе, Београд, 2020.

Govor predsednika Pahorja na slavnostni seji Sobranja Republike Severne Makedonije, https://www.predsednik.si/up-rs/uprs.nsf/objave/0490843 8A80F7354C12585EE00449283?OpenDocument, obiskal 19.april 2021. (Speech by president Pahor at the formal meeting of the Parliament of the Republic of North Macedonia)

Hajrullahu Muhamet, Ekskluzive, flet për Telegrafin Presidenti slloven Pahor një ditë para vizitës në Kosovë: Nuk e kam të njohur non-paper-in, idetë mbi ndryshimin e kufijve janë plotësisht të papranueshme, https://telegrafi.com/ekskluzive-flet-per-telegrafin-presidenti-sllovenpahor-nje-dite-para-vizites-ne-kosove-nuk-e-kam-te-njohur-non-paperidete-mbi-ndryshimin-e-kufijve-jane-plotesisht-te-papranueshme/, e vizituar 27 gusht 2021.

Halimić Erdin, Ambasador Velike Britanije u BiH Metju Fild za "Avaz": Timoti Les ne govori u ime Ujedinjenog Kraljevstva, https://avaz.ba/vijesti/bih/ 
649925/ambasador-velike-britanije-u-bih-metju-fild-za-avaz-timoti-lesne-govori-uime-ujedinjenog kraljevstva?fbclid=IwAR2uixGroqM5d4-P1PCKhWi_ef7Sv2fl_xOOvlw3pGLYUNOycoZPt9v3a8, posećeno 13. maj 2021. Izetbegović: "Non paper" iznosi teze opasne po Evropu, a ne samo BiH!https://politicki.ba/news/read/15980, posećeno 26. avgust 2021.

Janez Janša, https://twitter.com/JJansaSDS/status/1381546181956878340, obiskalo 26. avgusta 2021.

Janez Janša, https://twitter.com/JJansaSDS/status/1381953503506087942, obiskalo 26. avgust 2021.

Јанша предложил поделба на границите на Балканот?, https://news1.mk/archives/25643, посећено 26. август 2021.

Komšić potvrdio da je Pahor pitao da li je moguć miran razlaz u BiH, pa otkrio šta je Dodik odgovorio na to,https://www.oslobodjenje.ba/vijesti/ bih/ komsic-potvrdio-da-je-pahor-pitao-da-li-je-moguc-miran-razlaz-u-bih-paotkrio-sta-je-dodik-odgovorio-na-to-647019, posećeno 25. avgust 2021.

Mihalović Novica, Slovenski non-paper obstaja, a je za javnost preveč tvegan, https://www.delo.si/novice/ slovenija/slovenski-non-paper-je-za-javnostprevec-tvegan/, obiskal 27. avgust 2021.

Ministar Grlić Radman predstavio non-paper o Bosni i Hercegovini na Vijeću za vanjske poslove EU, http://www.mvep.hr/hr/mediji/priopcenja/, 36443.html, posjećeno 9. kolovoz 2021.

Мирни разлаз БиХ је најбољи за све, https://www.youtube.com/ watch?v=QTOWjMh9bkw, посећено 26. август 2021.

Non-paper on the implementation of the EU-UK TCA in the field offoreign and security policy, Council of the European Union/General Secretariat, WK 8452/2021 INIT LIMITE Brussels, 24 June 2021.

Numanović Sead, Janša predvodi države EU koje žele "veliku Srbiju" i komadanje BiH, Crne Gore, Sjeverne Makedonije, https://politicki.ba/ news/read/15926, posećeno 25. avgust 2021.

Navodni Janšin non-paper o BiH sam vidio na portalu, Hrvatska ga nije dobila', https://www.jutarnji.hr/vijesti/hrvatska/navodni-jansin-non-paper-o-bihsam-vidio-na-portalu-hrvatska-ga-nije-dobila-15065912, posećeno 27. avgust 2021. 
Papandreou George A., Europe and the Balkans - opening Pandora'sbox? https://www.ekathimerini.com/opinion/1164270/europe-and-thebalkans-opening-pandora-s-box/, visited July 19, 2021.

Peter Žerjavič, https://twitter.com/tfajon/status/1381612387896336385, obiskalo 25. avgusta 2021.

Portparol EK: Pitanje granica na Zapadnom Balkanu ,zauvek zatvoreno', https://www.slobodnaevropa.org/a/31223440.html, posećeno 26. april 2021.

POROČILO G. MILANA KUČANA, POROČEVALCA PREDSEDNIKU VLADE REPUBLIKE SLOVENIJE G. BORUTU PAHORU O MOŽNIH POTEH ZA USPEŠNO NADALJEVANJE PROCESA SPREMEMB USTAVNEGA REDA V REPUBLIKI BOSNI I HERCEGOVINI, REPUBLIKA SLOVENIJA/KABINET PREDSEDNIKA VLADE, Ljubljana, 11. 6. 2021.

PosebnasjednicaNSRSovisokompredstavniku; ObraćanjeMiloradaDodika, https://www.youtube.com/watch?v=C7mgcMDMrMI\&t=4087s, 1:07:471:08:00, посећено 13. август 2021.

Satou: Diplomatska praksa, Urednik izdanja Ser Ajvor Roberts, HOLLIWELLNEOPREN, Beograd, 2009.

Штављанин Драган, Први председник Словеније: крај Југославије је био неминован, https://www.slobodnaevropa.org/a/prvi-predsednik-slovenije-milan-kucan-intervju/31313878.html, посећено 28. јуна 2021.

Tanja Fajon, https://twitter.com/tfajon/status/1381612387896336385, obiskal 25. avgust 2021.

Tanja Fajon, https://twitter.com/tfajon/status/1381613982340034564, obiskalo 25. avgust 2021.

Tanja Fajon, https://twitter.com/tfajon/status/1381964257072271370, obiskalo 26. avgust 2021.

Telegram From the Department of State to the Ambassy in Israel, in: Editor Alexsander R. Wieland, United States Government Publishing Office, Washington DC, 2018.

Western Balkans - a way forward, https://necenzurirano.si/clanek/ aktualno/objavljamo-slovenski-dokument-o-razdelitvi-bih-ki-ga-isce-vesbalkan-865692\#gallery-2, obiskal 15. april 2021. 
Western Balkans - a way forward, https://necenzurirano.si/clanek/aktualno /objavljamo-slovenski-dokument-o-razdelitvi-bih-ki-ga-isce-ves-balkan865692\#gallery-2-https://necenzurirano.si/clanek/aktualno/objavljamoslovenski-dokument-o-razdelitvi-bih-ki-ga-isce-ves-balkan-865692\#gallery -3, obiskal 15. april 2021.

Western Balkans - a way forward, https://necenzurirano.si/clanek/ aktualno/objavljamo-slovenski-dokument-o-razdelitvi-bih-ki-ga-isce-vesbalkan-865692\#gallery-3, obiskal 15. april 2021.

Выступление и ответы на вопросы СМИ Министра иностранных дел Российской Федерации С.В.Лаврова в ходе совместной прессконфреренции с Министром иностранных дел Республики Сербии H.Селаковичем, Москва, 16 апреля 2021 года, https://www.mid.ru/ ru/vizity-ministra/-/asset_publisher/ICoYBGcCUgTR/content/id/4689215, доступ 19 апреля 2021 г.

ZGJEDHJE 2021 nё V+, https://www.facebook.com/edirama.al/videos/ 923087461838528, 2:15:45-2:15:50, e vizituar 26 gusht 2021. 